\title{
The geographic distribution of Knowledge Economy (KE) within the European Union (EU)
}

\author{
Shahrazad HADAD \\ The Bucharest University of Economic Studies, Bucharest, Romania \\ The Academy of Romanian Scientist, Bucharest, Romania \\ shahrazad.hadad@fabiz.ase.ro
}

\begin{abstract}
The business environment is reshaped by knowledge economy which has taken both competitiveness and doing business to a whole new level. Because knowledge economy plays a key role in the creation of welfare it has been classified as an important reliable indicator for comparing world's economies. The present paper highlights the geographic distribution of knowledge economy at the level of the European Union by means of factorial analysis. Factor analysis, a well-known statistical clustering technique, has been applied on the 28 EU countries (seen in our study as random variables) with an a priori fixed number of two factors. On each variable, the realisations are given by the scores (normalized between 0 and 1) registered for year 2012 on 12 key Knowledge Economy (KE) indices. The resulting factor structure is compared to the standard geographical grouping of EU countries (NorthWest-SouthEast) in present KE literature. SPSS software has been used for the statistical analysis. The highest correlations attained were in terms of the Global Competitiveness Index, World Happiness Index, $R \& D$ expenses signifying that they could also act as predictors in evaluating the status of the knowledge economy of a particular country, whereas weaker correlations can be spotted for enterprises selling online, electric energy consumption, carbon dioxide emissions and others. In the future, the same relationship can be tested to see whether the influences have changed, in the light of new available data.
\end{abstract}

Keywords: knowledge economy, competitiveness, innovation, competitiveness index, sustainability.

Please cite the article as follows: Hadad, S. (2018), "The geographic distribution of Knowledge Economy (KE) within the European Union (EU)", Management \& Marketing. Challenges for the Knowledge Society, Vol. 13, No. 3, pp. 1089-1107, DOI: 10.2478/mmcks-2018-0025.

\section{Introduction to knowledge economy, competitiveness, innovation and their key drivers}

The precursors of knowledge economy (KE) can be traced back to the works of Machlup (1962) and Drucker $(1969,2017)$, who discussed about the transition from the industrial economy to the knowledge economy, and to the post-industrialist theories of Bell (1973). Despite the plethora of already existing definitions developed by multiple researchers (Powell and Snellman, 2004), the one most commonly acknowledged is developed by Organisation of Economic Cooperation and Development (OECD) (1996) which regards knowledge economies as being "economies which are directly based on the production, distribution, and use of knowledge and information" (p. 7). Because knowledge economy plays a key role in the creation of welfare it has been classified as an important reliable indicator for comparing world's economies (Brinkley, 2006). 
Moreover, we consider competition to be among the key drivers of any economy and society. Competition, in general terms, may be defined as the rivalry between the different players on a market, in which each seller is trying to obtain sales, profit and market share by offering the best combination of price, quality and service. However, a modern approach to competition is that it is based in the changes occurring in the labour process or in the organization of production (Bratianu, 2017), idea that lead to a rather different definition for this term being considered the external expression of the internal drive of capital as capital to expand, to produce surplus value, and realize it in the form of profit (Jessop, 2014).

A competitive market is one in which multiple producers compete in trying to satisfy the needs of a large number of consumers. In the ideal scenario of a perfectly competitive market, no single producer, or group of producers and no single consumer or group of consumers can dictate how the market operates or individually determine the price or quantity of goods exchanged. Throughout the years, researchers have tried to establish a way to measure the competitiveness of a business, and they have learned that by looking at factors such as growth rate, net profit margin, returns on investment, market share, brand reputation or unique selling point, they could completely describe a firm operating in its external environment. However, when it comes to measuring the competitiveness of a country, issues become much more complex.

According to the World Economic Forum (WEF) (2013, 2016), competitiveness represents a set of institutions, policies and factors that determine the level of productivity in a country. At the same time, the productivity level determines the rates of return obtained by investments in an economy and the level of prosperity that can be reached by that economy. The process of understanding the drivers of competitiveness has been long debated starting from Adam Smith's focus on division and specialisation of labour to current interest on investment in physical capital and infrastructure (idem), and knowledge.

Nowadays, other factors such as education, training, technological progress, good governance, market efficiency, firm sophistication, among others, are taken into account when trying to measure competitiveness (Bejinaru, 2017; WEF, 2016). However, it has also been shown that all these factors and many others are interconnected, being relevant for a single economy, which lead to the development of the global competitiveness index computed based on twelve pillars for every country in the world.

Economic welfare is determined by various factors, among which we can find competition and innovation. For instance, Engels was favouring the existence of capitalism as being conditioned by the constant improvement and revolutionising of production tools (Stelzer, 2002), thus putting innovation at the core of an economic system operated by competitive markets.

Schumpeter (1942), the undisputed father of the economics of technological change, referred to capitalism as "the perennial gale of creative destruction" (p. 83) explaining the now famous term of creative destruction which is an industrial mutation process pursuing the destruction of an economic system from within, in order for it to be replaced with a new one. 
Furthermore, innovation has been considered one of the most important sources for companies to draw their competitive advantages from, perfectly portraying the competitive advantage strategy (Porter, 2011). Generally, some measures for innovation may be $R \& D$ expenses (also as percentage of GDP if considered country-wise), average number of patents granted or average number of employees working on $R \& D$, and the list may continue. Although it is rather difficult to measure it, emotional knowledge and emotional intelligence have a critical role in stimulating innovation (Bratianu \& Orzea, 2013). However, in this regard, as in the case of competitiveness, one can also refer to a country's general propensity towards innovation, and in this case many drivers must be considered for conducting a proper study. The global innovation index aims to take into account the multi-dimensional facets of innovation, being both a measuring tool and one whose goal is to improve countries' innovation performances.

The first objective of the present research was to establish whether Knowledge Economy Index (KEI), Global Competitiveness Index (GCI), Global Innovation Index (CII), World Happiness Index (WHI), Gini Index, Research and Development expense (as percentage of GDP), Number of scientific and technical articles in journals, GDP per capita, governmental expenditure per student, In bound mobility rates, Foreign Direct Investment Net Flows, High tech exports (as percentage of manufactured goods), Military Expense (as percentage of GDP), Electric power consumption kwh per capita, Energy use (kg of oil equivalent per capita), CO2 emissions (metric tons per capita), Households with internet access (\%), Daily frequency of internet access (\% individuals), Percentage of enterprises selling online are correlated. In order to conduct such an analysis we resorted to the bivariate covariances between each and every pair of the previously listed indices. Furthermore, the second objective of the paper aimed to investigate by means of factorial analysis (Principal Component Analysis - PCA) whether the geographic distribution of the countries of the European Union influences their knowledge economy propensity.

\section{Literature review and conceptual framework}

Knowledge Economy Index (KEI) was designed by the World Bank $(2009,2012)$ based on a simple arithmetic mean of four subindexes, namely the pillars of knowledge economy: Economic Incentive and Institutional Regime (EIR); Innovation and Technological Adoption; Education and Training; Information and Communications Technologies (ICT) Infrastructure, (idem, Chen and Dahlman, 2005).

According to Hadad (2017), knowledge economy is characterized by open innovation, education, knowledge management and creativity that are grounded in Information and Communication Technologies (ICT) and the existence of highly trained and well educated workers. In this respect, the generation of knowledge and access to Internet makes consumers more knowledgeable and aware in respect to the decisions they take (Vatamanescu et al., 2017) and, implicitly, more educated.

Skrodzka (2016) conducted a geographic research that underlined a positive influence of knowledge economy pillars on the knowledge economy development of European Union countries, accompanied by a strong positive relationship between knowledge economy development and the economic development level. 
In their empirical investigation on EU growth, convergence and the knowledge economy, Caraveli et al. (2008) established that investment in medium education, knowledge sectors and patent number positively influence economic growth and income disparities among EU regions. Moreover, the authors spot an unbalanced distribution of knowledge in a geo-economic context of EU-15. They advocate for policy measures which can proliferate knowledge-based activities in different regions that can further ripple into heightened innovation rate, sustainable growth and, ultimately, engender income disparities contraction. Concomitantly, peripheral regions can benefit from $R \& D$ subsides and knowledge infrastructure creation.

Some authors propose a linear, positive relationship between interfirm competition and knowledge acquisition based on previous studies showing that not only does alliance partners' protection not lower the magnitude of the knowledge flow between firms (Simonin, 1999; Norman and MacDonald, 2004), but it increases the efficiency of resource pooling, consequently "interfirm competition essentially involves the acquisition of knowledge from alliance partners." (Zhang et al., 2010, p.79). To sum up, the logical inference that lies behind the results of this study is that competition is one of the factors that coexists in any strategic alliance and it fosters knowledge acquisition that becomes a mediator for knowledge creation; furthermore, knowledge creation leads to innovation so, competition is a factor that is directly and positively linked with a company's innovative efforts. On the long run, according to Voinescu and Moisoiu (2015) competitiveness is driven by sustainability and an imperious requirement to make it in the knowledge economy is to increase investments in both innovation and tech.

Hopman et al. (2010) reveal from their study conducted in the Netherlands whether a change in competition policy, from the abuse system to the new Competition Act based on the prohibition system that put an end to the era of cartel paradise had an effect on innovation. The authors used R\&D expenditures and patent applications as measures of innovative efforts, since these were considered to be most relevant for the policy. The study concluded that a transition to a more competitive environment, caused by a new policy, was relevantly and positively linked to an increase in intellectual property applications, and thus, to an increase in innovation and knowledge economy. Another result is that firms that operate in a more competitive environment also increase their efficiency concerning innovative efforts, obtaining more innovative output by using less innovative input (Hadad, 2017a-c). Moreover, the importance of vertical relationships is highlighted, since it was proven that cooperation with suppliers in innovative efforts leads to important increases both in the innovation intensity of the industry and the ratio of the firms with patent applications. The conclusion of this study is that the relationship between competition and innovation is a monotonously positive one.

Global Competitiveness Index (GCI), is made of twelve pillars divided in three subindexes: a) basic requirements: institutions, infrastructure, macroeconomic environment, health and primary education, b) efficiency enhancers: higher education and training, goods market efficiency, labour market efficiency, financial market development, technological readiness, market size, c) innovation and sophistication factors: business sophistication and innovation (WEF, 2016) 
In the attempt to align to the Europe 20202 Strategy, Priede and Neuer (2015) suggest that there is a considerable gap between EU countries in terms of competitiveness which can only be undersized by engaging in more intensive research and development investments.

Global Innovation Index (CII) The GII is composed of two sub-indices: Innovation Input Sub-Index and the Innovation Output Sub-Index, to form a total of seven pillars (Cornell University, INSEAD, and WIPO, 2014). The Innovation Input SubIndex refers to those elements of an economy that enable and support innovative activities: Institutions, Human capital and research, Infrastructure, Market sophistication and Business sophistication. The Innovation Output Sub-Index is built around the pillars that represent the results of the innovative efforts in an economy: Knowledge and technology outputs and Creative outputs. Therefore this index provides a close link to knowledge economy.

Higher average incomes do not necessarily lead to improvements in average well-being of the population. Increased economic output, which would implicitly mean higher incomes, has led to heightened $\mathrm{CO}_{2}$ emissions (metric tons per capita), electric power kwh consumption per capita, energy use ( $\mathrm{kg}$ of oil equivalent per capita) that have left the environment and wellbeing of society better off. In a knowledge economy, the three previously mentioned indicators would be expected to undergo decreasing trends given the availability of information and alternative sources of energy to use. As income has been proven not to necessarily impact the wellbeing of society on the long term, attention of researchers has shifted towards World Happiness Index (WHI). According to Helliwell et al. (2012) the measurement of WHI is based on the assessment of daily emotions (affective happiness) and the individual's overall evaluation of life (evaluative happiness). The authors describe that the happiness of a nation is not necessarily positively correlated to the Gross National Product (GNP) [and Gross Domestic Product (GDP) per capita], since the quest for higher income may impair one's happiness.

The Gini Index, also referred to as an inequality index, represents the measurement of income dispersion of a nation's population with the intent of highlighting the discrepancies is income or wealth distribution (Jenkins, 2017), where a 0 value serves as perfect equality, whereas 1 is the superior limit expressing the maximal inequality. The index has applications in education and opportunity analysis. Education is central to the knowledge based economy for ensuring that knowledge workers contribute to the development of human capital in knowledge industries (Danby and Lee, 2012; Lešera et al., 2018), therefore we assert that the progress of society can also be easily reflected in the governmental spending it incurs per students (governmental expenditure per student) and the level of inbound mobility rates in tertiary education.

Foreign Direct Investment (FDI) Net Flows - By using firm level panel data, Kinoshita (2000) discovered that the learning effect of R\&D acts as better predictor in explaining the productivity growth of a company as compared to the innovative effect and that positive FDI spillovers can be identified in the electrical machinery and radio and TV sectors. Additionally, FDIs have been proven to influence the national competitiveness and, at the same time, a crucial role on the absorptive capacity of the host state is played by the location or by the cluster it belongs to (Gugler and Brunner, 
2007) and innovation can play a significant role in the economic welfare for the countries within the cluster (Dan, 2011, 2012). Finally, Alvarez and Marin (2013) conclude that international competitiveness in high-tech industries is affected by different dimensions of internal and external factors.

The research conducted by Falk (2009) explains that business $R \& D$ intensity generates significant knowledge and its importance exceeds that of share of high-tech exports in explaining GDP per working age population, concluding therefore that high tech exports impact the development of OECD countries. Furthermore, Braunerhjelm, and Thulin (2008) argue that a one percentage point increase in R\&D expenditures triggers a three percentage point increase in high-tech exports leading to no significant market size change. Research and Development activities result in knowledge generation and have a crucial role in assessing cross-country competitiveness (Dzhukha et al., 2017; Ryzhkova, and Prosvirkin, 2015). Moreover, as knowledge economy deals with intangibles (Bratianu, 2018), the number of scientific and technical articles published in journals can be considered knowledge economy product categories, though this is a debatable indicator since quality should prevail over quantity. However, for now, this is the official global indicator provided by the World Bank. A better way of measuring the knowledge diffusion created through the scientific and technical articles would be the number of citations the articles have acquired in high ranking journals or through the journals' impact factors (Bernstein and Gray, 2012; Carpenter et al., 2014).

Concerning the Military Expense (as percentage of GDP) - the former EU Commission, President Barroso (2012) alleged that "the defense sector, apart from the political and other aspects is also crucial in terms of exports, cutting-edge research and provides growth and highly skilled jobs". In the same vein were the claims of Van Rompuy (2012) "a stronger defence industry which will contribute to more innovation and competitiveness and to more growth and employment across our Union". The military activity (defence-related R\&D investment) influences innovation in the broader civilian economy of several OECD nations (Mowery, 2012). However, the scope and nature of this influence remains uncertain and subject to considerable debate, this is why in the present research we decided to include the military expense (as percentage of GDP) indicator.

Competitiveness can be achieved if special attention is paid to the knowledge economy variables enacted by $R \& D$ expenditure as a percentage of the GDP, lifelong learning, and tertiary education attainment (Dima et al., 2018). Accordingly, GDP per capita is regarded as a potential influencer of competitiveness and knowledge since it represents both the standard of living of a country and the output of an economy. Another key driver of knowledge economy is digitisation which has been put in place, at EU level, by the Digital Agenda for Europe in the context of Europe 2020 Strategy which assesses 31 indicators grouped into five compounds: connectivity, human capital, use of Internet, integration of digital technology and digital public services. For our analysis we shall consider the percentage of households with internet access, daily frequency of internet access (\% individuals), and percentage of enterprises selling online.

From the present literature review we were led to elaborate on the following hypotheses: H1. There is a strong correlation between the enablers of knowledge 
economy: Knowledge Economy Index (KEI), Global Competitiveness Index (GCI), Global Innovation Index (CII), World Happiness Index (WHI), Gini Index, Research and Development expense (as percentage of GDP), Number of scientific and technical articles in journals, GDP per capita, governmental expenditure per student, In bound mobility rates, Foreign Direct Investment Net Flows, High tech exports (as percentage of manufactured goods), Military Expense (as percentage of GDP), Electric power consumption kwh per capita, Energy use ( $\mathrm{kg}$ of oil equivalent per capita), CO2 emissions (metric tons per capita), Households with internet access (\%), Daily frequency of internet access (\% individuals), Percentage of enterprises selling online; H2. The distribution of knowledge economy follows the geographic distribution of the countries within the EU.

\section{Research methodology and results}

United Nations Statistics Division (UNSD) (2013) has classified the countries of Europe (and implicitly the European Union) into two regions: the North + West and the South + East (Table 1).

Table 1. Regional EU clustering

\begin{tabular}{|l|l|}
\hline $\begin{array}{l}\text { “NorthWest Europe" Region } \\
\text { (I) }\end{array}$ & $\begin{array}{l}\text { "SouthEast Europe" Region } \\
\text { (II) }\end{array}$ \\
\hline Austria & Bulgaria \\
\hline Belgium & Croatia \\
\hline Denmark & Republic of Cyprus \\
\hline Estonia & Czech Republic \\
\hline Finland & Hungary \\
\hline France & Romania \\
\hline Germany & Slovakia \\
\hline Ireland & Slovenia \\
\hline Latvia & Poland \\
\hline Lithuania & Greece \\
\hline Luxembourg & Italy \\
\hline Netherlands & Malta \\
\hline Sweden & Portugal \\
\hline UK & Spain \\
\hline
\end{tabular}

Source: Author's own representation based on UNSD (2013).

Factor Analysis (FA) is a well-known clustering technique used in statistics and econometrics, relying heavily on probabilities, and sometimes acknowledged as Principal Component Analysis (PCA). FA applies to partitioning large sets of random variables into smaller, meaningful clusters, the centroid of each cluster being the socalled factor (Tabachnick and Fidell, 2007; Vizitiu et al., 2018, Agapie et al., 2018). Since the resulting number of factors is usually of an order of magnitude smaller than the initial number of variables, one expects from such analysis a better comprehension of the dependency among the variables, mathematically expressed by the correlation matrix (Habing, 2003). 
When there is no a priori information, the number of factors is left open, to be determined by the computer programme based on the eigenvalue criterion - see Stevens (2002) for a thorough discussion on this topic, and George and Mallery (2003) for the specifics of SPSS software, respectively. However, this is not the case with our study, where existent KE literature indicates, as pointed out in Introduction, a grouping of the 28 EU countries into two main clusters: NorthWest and SouthEast, thus downsizing the number of factors to two.

We started our numerical analysis by computing Pearson correlation coefficients among all pairs of economic indices presumably related to KE, namely: KEI; GII; GCI; World happiness index; R\&DGDP expense; Number of scientific and technical articles; Gini; GDP per capita; Government expenditures per student; Inbound mobility rate; FDI net inflows; High Tech Exports of manufactured goods; Military expense of GDP; Electric power consumption per capita; Energy use per capita; $\mathrm{CO}_{2}$ emissions metric per capita; Households with internet access; Daily frequency of internet access (\% of individuals); Enterprises selling online. The corresponding data was obtained from the World Bank Database (https://data.worldbank.org/) under the limitation that the newest KEI available data belongs to the 2012 cohort.

Out of the 18 indices initially proposed - separate from KEI, mandatorily placed in the benchmark, as being a reference index - only 11 are significantly correlated (at a cut-value of 0.5 ) with KEI, so the other seven are excluded from the statistical analysis (in italic in the list above, and in Table 2 below - on the next page).

A special case is the Gini equality coefficient, measuring the discrepancy of wealth distribution among a nation's population. This index is significantly negatively correlated with KEI, precisely at the cut-value 0.5 , so we chose to run two different analyses, one with Gini, and one without this index. As a general rule, we present in the following solely the numerical results of the analysis with Gini, the analysis without Gini being pretty much the same. The only notable exception is the slightly different structure of the clusters, to be presented in the subsequent.

Moving on to exploratory FA, we point out that in our case the variables are the EU countries, not the above KE indices. The values of these indices, corresponding to each country, are considered as realisations of the random variables. In order to extract the two factors, we applied the SPSS Dimension Reduction $\rightarrow$ Factor procedure, using the Principal Component extraction method, Varimax with Kaiser normalization rotation, on the 28-item set of EU countries, on a sample of 12 (respectively 11, when Gini is excluded) - values for the KE indices. 
Table 2. Correlation matrix for proposed Knowledge Economy indices

\begin{tabular}{|c|c|c|c|c|c|c|c|c|c|c|c|c|c|c|c|c|c|c|c|c|}
\hline & & KEI & 1 & 2 & 3 & 4 & 5 & 6 & 7 & 8 & 9 & 10 & 11 & 12 & 13 & 14 & 15 & 16 & 17 & 18 \\
\hline & KEI & 1 & & & & & & & & & & & & & & & & & & \\
\hline 1 & GII & $.901^{* *}$ & 1 & & & & & & & & & & & & & & & & & \\
\hline 2 & GCI & $.894^{* *}$ & $.887^{* *}$ & 1 & & & & & & & & & & & & & & & & \\
\hline 3 & WHI & $.855^{* *}$ & $.779^{* *}$ & $.816^{* *}$ & 1 & & & & & & & & & & & & & & & \\
\hline 4 & $\begin{array}{l}\text { R\&DGDPexpens } \\
\text { e }\end{array}$ & $.844^{* *}$ & $.735^{* *}$ & $.799^{* *}$ & $.697^{* *}$ & 1 & & & & & & & & & & & & & & \\
\hline 5 & $\begin{array}{l}\text { NoSciampTechart } \\
\text { icles }\end{array}$ & .310 & .221 & $.451^{*}$ & .279 & .253 & 1 & & & & & & & & & & & & & \\
\hline 6 & Gini & $\begin{array}{r}- \\
.502^{* *} \\
\end{array}$ & $-.417^{*}$ & $-.478^{*}$ & $-.417^{*}$ & $.588^{* *}$ & -.350 & 1 & & & & & & & & & & & & \\
\hline 7 & GDPpercapita & $.693^{* *}$ & $.704^{* *}$ & $.732^{* *}$ & $.784^{* *}$ & $.517^{* *}$ & .181 & -.202 & 1 & & & & & & & & & & & \\
\hline 8 & $\begin{array}{l}\text { Govexpendperstu } \\
\text { dent }\end{array}$ & .241 & .295 & 166 & .207 & .355 & -.240 & -.074 & -.003 & 1 & & & & & & & & & & \\
\hline 9 & $\begin{array}{l}\text { Inboundmobilityr } \\
\text { ate }\end{array}$ & .257 & $.387^{*}$ & $.396^{*}$ & $.439^{*}$ & .095 & 145 & -.065 & $.755^{* *}$ & -.267 & 1 & & & & & & & & & \\
\hline 10 & FDINetInflows & .317 & .372 & $.416^{*}$ & $.379^{*}$ & .034 & .203 & -.137 & $.517^{* *}$ & $-.404^{*}$ & $.504^{* *}$ & 1 & & & & & & & & \\
\hline 11 & $\begin{array}{l}\text { HighTechExports } \\
\text { ofmanufgoods }\end{array}$ & .262 & $.439^{*}$ & .238 & .251 & .050 & .158 & -.199 & .105 & $.394^{*}$ & .096 & .163 & 1 & & & & & & & \\
\hline 12 & $\begin{array}{l}\text { Militaryexpenseof } \\
\text { GDP }\end{array}$ & -.159 & -.262 & -.105 & -.165 & -.041 & $.422^{*}$ & .172 & -.280 & -.329 & -.178 & -.132 & -.218 & 1 & & & & & & \\
\hline 13 & $\begin{array}{l}\text { Electricpowerco } \\
\text { nsumptionkwh } \\
\text { percapita }\end{array}$ & $.669^{* *}$ & $.655^{* *}$ & $.672^{* *}$ & $.624^{* *}$ & $.679^{* *}$ & .012 & -.279 & $.757^{* *}$ & .191 & $.462^{*}$ & .242 & -.042 & -.176 & 1 & & & & & \\
\hline 14 & $\begin{array}{l}\text { Energyusekgofo } \\
\text { ilequivalentper } \\
\text { capita }\end{array}$ & $.653^{* *}$ & $.643^{* *}$ & $.685^{* *}$ & $.616^{* *}$ & $.618^{* *}$ & .035 & -.326 & $.787^{* *}$ & .028 & $.553^{* *}$ & $.431^{*}$ & -.056 & -.237 & $.919^{* *}$ & 1 & & & & \\
\hline 15 & $\begin{array}{l}\mathrm{CO}_{2} \text { emissionsmetr } \\
\text { ictonspercapita }\end{array}$ & .355 & $.409^{*}$ & .365 & .359 & .227 & -.029 & -.183 & $.651^{* *}$ & -.229 & $.649^{* *}$ & $.523^{* *}$ & -.023 & -.200 & $.563^{* *}$ & $.765^{* *}$ & 1 & & & \\
\hline 16 & $\begin{array}{l}\text { Householdswith } \\
\text { internetaccess }\end{array}$ & $.858^{* *}$ & $.889^{* *}$ & $.862^{* *}$ & $.842^{* *}$ & $.696^{* *}$ & .259 & $.511^{-}$ & $.778^{* *}$ & .238 & $.421^{*}$ & $.466^{*}$ & .351 & -.247 & $.657^{* *}$ & $.695^{* *}$ & $.465^{*}$ & 1 & & \\
\hline 17 & $\begin{array}{l}\text { Dailyfrequency } \\
\text { ofinternetacces } \\
\text { sindivid }\end{array}$ & $.845^{* *}$ & $.859^{* *}$ & $.844^{* *}$ & $.763^{* *}$ & $.667^{* *}$ & .212 & $-.399^{*}$ & $.775^{* *}$ & .171 & $.425^{*}$ & $.444^{*}$ & .274 & -.184 & $.694^{* *}$ & $.717^{* *}$ & $.431^{*}$ & $.946^{* *}$ & 1 & \\
\hline 18 & $\begin{array}{l}\text { Enterprisesselli } \\
\text { ngonline }\end{array}$ & $.688^{* *}$ & $.631^{* *}$ & $.566^{* *}$ & $.629^{* *}$ & $.581^{* *}$ & .103 & $.540^{-*}$ & $.417^{*}$ & .155 & .085 & .121 & .243 & -.234 & .371 & $.379^{*}$ & .146 & $.612^{* *}$ & $.529^{* *}$ & 1 \\
\hline
\end{tabular}

**. Correlation is significant at the 0.01 level (2-tailed); *. Correlation is significant at the 0.05 level (2-tailed).

Source: Author's representation based on own research.

Vol. 13, No. 3, Autumn, pp. 1089-1107, ISSN 1842-0206 | Management \& Marketing. Challenges for the Knowledge Society 
The two resulted factors partitioned the EU countries into two groups, one with 20 and the other with eight countries, see Table 3 . The cumulative total variance explained by the two factors is $86.084 \%$.

Table 3. Clustering the EU countries with respect to Knowledge Economy indices

\begin{tabular}{|l|l|}
\hline Factors & Variables \\
\hline Group 1 & $\begin{array}{l}\text { Austria, Bulgaria, Croatia, Cyprus, Estonia, France, Greece, Hungary, Ireland, Italy, Latvia, } \\
\text { Lithuania, Luxembourg, Malta, Poland, Portugal, Romania, Slovak Republic, Spain, UK }\end{array}$ \\
\hline Group 2 & Belgium, Czech Republic, Denmark, Finland, Germany, Netherlands, Slovenia, Sweden \\
\hline
\end{tabular}

Source: Author's representation based on own research.

Another statistical instrument employed in relation with FA represented by the Cronbach's alpha coefficients. Originally intended for social studies based on surveys where the answer to each question follows a finite-range Likert scale, Cronbach's alpha is the most common measure of a scale's internal consistency (Tabachnick and Fidell 2007; Craciun et al., 2015). In our case, we have rescaled all KE indices within the interval $[0,1]$, so Cronbach's alpha coefficients were computed for each of the two resulting factors, in order to determine whether the scale used is reliable with respect to the items composing each factor.

Table 4. Cronbach's alpha coefficient for Factor 1

\begin{tabular}{|c|c|c|c|c|}
\hline & $\begin{array}{c}\text { Scale Mean if Item } \\
\text { Deleted }\end{array}$ & $\begin{array}{l}\text { Scale Variance } \\
\text { if Item Deleted }\end{array}$ & $\begin{array}{l}\text { Corrected } \\
\text { Item-Total } \\
\text { Correlation }\end{array}$ & $\begin{array}{l}\text { Cronbach's } \\
\text { Alpha if Item } \\
\text { Deleted }\end{array}$ \\
\hline Austria & 11.326 & 19.747 & 0.767 & 0.989 \\
\hline Bulgaria & 11.587 & 18.832 & 0.931 & 0.988 \\
\hline Croatia & 11.498 & 19.135 & 0.815 & 0.989 \\
\hline Cyprus & 11.515 & 18.687 & 0.967 & 0.988 \\
\hline Estonia & 11.406 & 19.292 & 0.895 & 0.988 \\
\hline France & 11.358 & 19.407 & 0.928 & 0.988 \\
\hline Greece & 11.548 & 19.017 & 0.940 & 0.988 \\
\hline Hungary & 11.506 & 18.945 & 0.969 & 0.988 \\
\hline Ireland & 11.341 & 19.311 & 0.861 & 0.989 \\
\hline Italy & 11.484 & 19.000 & 0.931 & 0.988 \\
\hline Latvia & 11.523 & 18.579 & 0.984 & 0.988 \\
\hline Lithuania & 11.501 & 18.877 & 0.962 & 0.988 \\
\hline Luxembourg & 11.196 & 20.600 & 0.282 & 0.992 \\
\hline Malta & 11.464 & 18.892 & 0.952 & 0.988 \\
\hline Poland & 11.527 & 18.881 & 0.987 & 0.988 \\
\hline Portugal & 11.491 & 19.078 & 0.952 & 0.988 \\
\hline Romania & 11.609 & 18.605 & 0.959 & 0.988 \\
\hline Slovak Republic & 11.495 & 19.156 & 0.935 & 0.988 \\
\hline Spain & 11.445 & 19.011 & 0.988 & 0.988 \\
\hline UK & 11.333 & 19.029 & 0.928 & 0.988 \\
\hline
\end{tabular}

Source: Author's representation based on own research. 
In our case, each of the two obtained factors (groups of countries) was subsequently tested for internal consistency in SPSS using the Cronbach's alpha coefficient technique. Factor 1 checked with a Cronbach value of 0.989, while Factor 2 checked with a Cronbach value of 0.945 .

Table 5. Cronbach's alpha coefficient for Factor 2

\begin{tabular}{|l|r|r|r|r|}
\hline & \multicolumn{1}{|c|}{$\begin{array}{c}\text { Scale } \\
\text { Mean if } \\
\text { Item } \\
\text { Deleted }\end{array}$} & $\begin{array}{c}\text { Scale } \\
\text { Variance } \\
\text { if Item } \\
\text { Deleted }\end{array}$ & $\begin{array}{c}\text { Corrected } \\
\text { Item-Total } \\
\text { Correlation }\end{array}$ & $\begin{array}{c}\text { Cronbach's } \\
\text { Alpha if } \\
\text { Item } \\
\text { Deleted }\end{array}$ \\
\hline Belgium & 5.371 & 1.503 & 0.944 & 0.930 \\
Czech & 5.482 & 1.465 & 0.765 & 0.940 \\
Republic & 5.315 & 1.395 & 0.836 & 0.935 \\
Denmark & 5.260 & 1.621 & 0.576 & 0.951 \\
Finland & 5.405 & 1.396 & 0.811 & 0.938 \\
Germany & 5.348 & 1.425 & 0.827 & 0.936 \\
Netherlands & 5.488 & 1.454 & 0.893 & 0.931 \\
Slovenia & 5.230 & 1.561 & 0.853 & 0.937 \\
Sweden & \multicolumn{2}{|r}{}
\end{tabular}

Source: Author's representation based on own research.

A detailed Cronbach analysis of the two factors is depicted in Table 4 and Table 5 , respectively. One should notice that the last column of both tables presents the Cronbach values in the case of deletion of the corresponding variable. We can see that removal of Luxembourg would result in a small improvement in Cronbach's alpha. On the other hand, one should notice that the Corrected Item-Total Correlation value for Luxembourg is low (0.282), which sets this country as an outlier that can be further removed from the statistical analysis. After performing this operation, the cumulative total variance explained by the two factors increases to $87.463 \%$.

The graphical representation of the partitioning of the 27 (minus Luxembourg) EU countries into two clusters is depicted in Figure 1. 


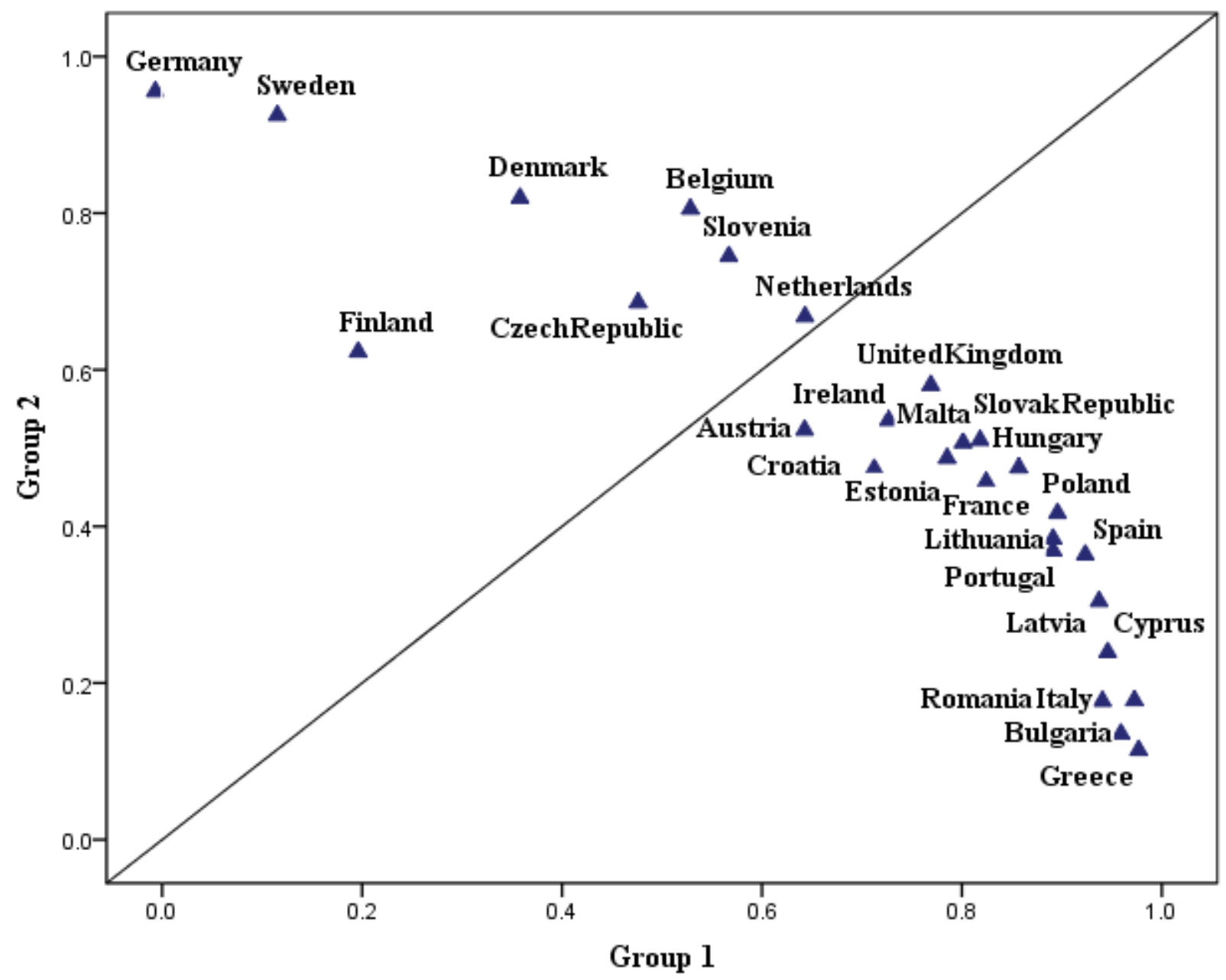

Figure 1. Distribution of EU countries with respect to Knowledge Economy - case with Gini Source: Author's representation based on own research.

The slightly different partition provided by the same FA, but without including the Gini index, is given in Figure 2 (Annex 1). However, one can observe that the countries pertaining to Group 1 exhibit better clustering.

The differences between the two analyses (with or without the Gini index) are the following: a) in the first case the countries appear to be more scattered as compared to the second one; b) Finland and Portugal permute from one group to another, from the first to the second analysis; c) Ireland migrates from Group 1 to Group 2, from the first to the second analysis.

The graphical representation of the cross distribution between the regional classification and the FA clusters is depicted in Annex 2 (Figure 3). The two regional clusters are listed in ascending order from left to right, 14 countries in each cluster, while the two FA clusters are represented in colors (green versus blue). As one can notice, the differences are quite significant implying that the popular geographical dichotomy between NorthWest and SouthEastern European countries does not hold true. 


\section{Conclusions}

The first part of this research paper was dedicated to investigating knowledge economy and the multitude of factors influencing it. We started our analysis from the hypothesis that KEI follows the geographical (and wealth) distribution among European countries. In order to test this hypothesis, we first performed a pairwise covariance analysis of 18 potential KE related indices which downsized their number to $12, \mathrm{KEI}$ included. In the next step of the research, we modelled the $28 \mathrm{EU}$ countries as random variables, the normalized values of the 12 indices being their instantiations. To these 28 variables, a factor analysis procedure was applied in SPSS with a fixed number of two factors as the output. Finally, we compared the two factor obtained structure against the existing regional classification offered by the United Nations Statistics Division (2013). We can conclude that the geographical distribution of the EU countries does not exert a significant influence on the knowledge economy index, since the two classifications (geographical and statistical) do not exhibit any overlapping pattern, therefore infirming our second hypothesis. Our first hypothesis was partially confirmed since not all the factors identified exert string influence on the knowledge economy.

For example, we would expect that the number of scientific and technical articles, governmental spending per student and the inbound mobility rate would have an important influence over knowledge economy, however the factors were excluded from the factorial analysis next to FDI net inflows, high tech exports of manufactured goods, military expenses as percentage of GDP and carbon dioxide emissions as metric tons per capita. In terms of knowledge economy, Romania is strongly influenced by Greece, Cyprus, Latvia, Bulgaria, Slovak Republic and Italy and this could represent a common ground for working towards harmonised policies for encouraging knowledge economy, innovation, competitiveness and digitisation. The highest correlations attained were in terms of the Global Competitiveness Index, World Happiness Index, R\&D expenses signifying that they could also act as predictors in evaluating the status of the knowledge economy of a particular country, whereas weaker correlations can be spotted for enterprises selling online, electric energy consumption, carbon dioxide emissions and others. In the future, the same relationship can be tested to see whether the influences have changed, in the light of new available data.

The main limitations of this study reside in the fact that the newest KEI corresponding data which was available from the World Bank Database belonged to the 2012 cohort and that after infirming the geographic distribution, we did not render a sound criterion for the grouping of the countries. Additionally future investigations could be devoted to conducting a similar analysis however not setting the number of factors to two. Another way of identifying knowledge economy clusters may be done by using Analytic Hierarch Process (AHP) or Analytic Network Process (ANP) and establishing an economically valid grouping criterion.

\section{Acknowledgements}

The present paper has been financially supported by the Academy of Romanian Scientists, Programme No. 15/2018 "Strategies for Implementing Knowledge Economy in Romania". 


\section{References}

Agapie, A., Vizitiu, C., Cristache, S., Năstase, M., Crăciun, L., \& Molănescu, A. (2018). "Analysis of Corporate Entrepreneurship in Public R\&D Institutions". Sustainability, Vol. 10, No. 7, pp. 2297, 1-15.

Alvarez, I., \& Marin, R. (2013). "FDI and technology as levering factors of competitiveness in developing countries". Journal of International Management, Vol. 19, No. 3, pp.232-246.

Barroso, J.M.D. (2012) Statement by President Barroso following the second day of the European Council, 13-14 December 2012, Available online http://europa.eu/rapid/press-release_SPEECH-12-959_en.htm.

Bejinaru, R. (2017). "Knowledge strategies aiming to improve the intellectual capital of universities". Management \& Marketing. Challenges for the Knowledge Society, Vol. 12, No. 3, pp. 500-523.

Bell, D. (1973). The coming of the post-industrial age: A venture in social forecasting. London: Heinemann.

Bernstein, J., \& Gray, C. F. (2012). "Content factor: a measure of a journal's contribution to knowledge". PLoS One, Vol. 7, No. 7, e41554.

Bratianu, C. (2017). Sharing economy: knowledge strategies for crazy times. In Tsui, E. \& Cheung, B. (Eds.). Proceedings of the $14^{\text {th }}$ International Conference on Intellectual Capital, Knowledge Management and Organizational Learning, The Hong Kong Polytechnic University, Hong Kong (pp. 29-35), 7-8 December 2017. Reading: Academic Conferences and Publishing International.

Bratianu, C. (2018). "Intellectual capital research and practice: 7 myths and one golden rule". Management \& Marketing. Challenges for the Knowledge Society, Vol. 13, No. 2, pp. 859-879.

Bratianu, C. \& Orzea, I. (2013). Emotional knowledge: the hidden part of the knowledge iceberg. In Janiunaite, B., Pundziene, A. \& Petraite, M. (Eds.). Proceedings of the $14^{\text {th }}$ European Conference on Knowledge Management, Kaunas University of Technology, Lithuania (Vol.1, pp. 82-90), 5-6 September 2013. Reading: Academic Conferences and Publishing International.

Braunerhjelm, P., \& Thulin, P. (2008). "Can countries create comparative advantages? R\&D expenditures, high-tech exports and country size in 19 OECD countries, 1981-1999". International Economic Journal, Vol. 22, No. 1, pp. 95-111.

Brinkley, I. (2006). Defining the knowledge economy, Knowledge economy programme report, DTI Competitiveness White Paper, The Work Foundation, http://www.theworkfoundation.com/assets/docs/publications/65_defining\% 20knowledge\%20economy.pdf.

Caraveli, H., Tsionas, E. G., \& Darzentas, J. (2008). "EU Growth, Convergence and the knowledge economy: an Empirical Investigation". The Journal of Economic Asymmetries, Vol. 5, No. 2, pp. 105-124.

Carpenter, C. R., Cone, D. C., \& Sarli, C. C. (2014). "Using publication metrics to highlight academic productivity and research impact". Academic Emergency Medicine, Vol. 21, No. 10, pp. 1160-1172.

Chen, D. and Dahlman, C.J. (2005). The Knowledge Economy, the KAM Methodology and World Bank Operations, World Bank Institute, Working Paper 37256, http://papers.ssrn.com/sol3/papers.cfm?abstract_id=841625. 
Cornell University, INSEAD and WIPO (2013) "The Global Innovation Index 2013: The Local Dynamics of Innovation", Geneva, Ithaca and Fontainebleau.

Craciun, L., Nastase, M., Stamule, T. \& Vizitiu, C. (2015), “Leadership in Romanian small to medium enterprises", Sustainability, No. 7, pp. 4183-4198.

Dan, M.C. (2011). Competitiveness, regional development and clusters in the Romanian context. In Proceedings of the 6th International Conference on Business Excellence. Brașov: Publishing House of the Transilvania University of Brasov (pp. 165-168).

Dan, M.C. (2012). "Innovative clusters: a solution for the economic development of Romania". Theoretical \& Applied Economics, Vol. 19, No. 9, pp. 25-16.

Danby, S. and Lee, A. (2012). Framing doctoral pedagogy as design and action. In Lee, A. \& Danby, S. (eds). Reshaping doctoral education:International approaches and pedagogies. Abington: Routledge.

Dima, A.M., Begu, L., Vasilescu, M.D., \& Maassen, M.A. (2018). “The Relationship between the Knowledge Economy and Global Competitiveness in the European Union". Sustainability, Vol. 10, No. 6, pp. 1706, 1-15.

Drucker, P. (1969). The age of discontinuity. Elsevier.

Drucker, P. (2017). The age of discontinuity: Guidelines to our changing society. Routledge.

Dzhukha, M.V., Kokin, N.A., Li, S.A., \& Sinyuk, Y.T. (2017). "Research and Development Intensity in Business: Russia and EU". European Research Studies Journal, Vol., 20, No. 1, pp. 64-76.

Falk, M. (2009). "High-tech exports and economic growth in industrialized countries". Applied Economics Letters, Vol. 16, No. 10, pp. 1025-1028.

George, D. and Mallery, P. (2003), SPSS for Windows step by step: A simple guide and reference, 4th edn., Allyn \& Bacon, Boston, MA.

Gugler, P., \& Brunner, S. (2007). "FDI effects on national competitiveness: A cluster approach". International Advances in Economic Research, Vol. 13, No. 3, pp. 268-284.

Habing, B. (2003). Exploratory factor analysis, Personal communication, 15 October, University of South Carolina, viewed March 102017 from http://people.stat.sc.edu/habing/courses/530EFA.pdf

Hadad, S. (2017a). "Knowledge economy: Characteristics and dimensions". Management dynamics in the Knowledge economy, Vol. 5, No. 2, pp. 203-225.

Hadad, S. (2017b). "Strategies for developing knowledge economy in Romania". Management \& Marketing, Challenges for the Knowledge Society, Vol. 12, Vol. 3, pp. 416-430.

Hadad, S. (2017c). "Business Digitization in the Romanian Economy", in Proceedings of Strategica. Shift. Major challenges of today`s economy.

Helliwell, J., Layard, R. and Sachs, J. (eds.) (2012). World happiness report. The Earth Institute, Columbia University, New York, USA.

Hopman C., Rojas-Romagosa H., Veenendaal P. (2010). The relation between competition and innovation: Empirical results and implementation into WorldScan, CPB Netherlands Bureau for Economic Policy Analysis, Sector: International Economics, Project: S6-147 Lissabon concurrentie en innovatie (MODELS III), No. 242.

INSEAD, WIPO (2012). The Global Innovation Index 2012: Stronger Innovation 
Linkages for Global Growth, Fontainebleau.

Jenkins, S. (2017). The measurement of income inequality. In Economic inequality and poverty: International perspectives (pp. 17-52). Routledge.

Jessop, B. (2013). The complexities of competition and competitiveness: challenges for competition law and economic governance in variegated capitalism. Asian Capitalism and the Regulation of Competition: Towards a Regulatory Geography of Global Competition Law, 96-120. [Accessed 9 Jun. 2018].

Kinoshita, Y. (2000). "R\&D and Technology Spillovers Via FDI: Innovation and Absorptive Capacity (November 2000)". William Davidson Institute Working Paper No. 349. Available at SSRN: https://ssrn.com/abstract=258194 or http://dx.doi.org/10.2139/ssrn.258194.

Lešera, V. J., Šircaab, N. T., Dermola, V., \& Trunka, A. (2018). “Career Opportunities for PhD Graduates in the knowledge-based Economy: Case of Slovenia". ProcediaSocial and Behavioral Sciences, Vol. 238, pp. 104-113.

Machlup, F. (1962). The production and distribution of knowledge in the United States (Vol. 278). Princeton university press.

Mowery, D. C. (2012). "Defense-related R\&D as a model for "Grand Challenges" technology policies". Research Policy, Vol. 41, No. 10, pp. 1703-1715.

Norman, W., \& MacDonald, C. (2004). "Getting to the bottom of "triple bottom line"'”. Business Ethics Quarterly, Vol. 14, No. 2, pp. 243-262.

OECD (1996). "The knowledge based economy". Retrieved from https://www.oecd.org/sti/sci-tech/1913021.pdf.

Porter, M. E. (2011). Competitive advantage of nations: creating and sustaining superior performance (Vol. 2). New York: Simon and Schuster.

Powell, W. W., \& Snellman, K. (2004). "The knowledge economy". Annual Review of Sociology., Vol. 30, pp. 199-220.

Priede, J., \& Neuert, J. (2015). “Competitiveness Gap of the European Union Member Countries in the Context of Europe 2020 Strategy". Procedia-Social and Behavioral Sciences, Vol. 207, pp. 690-699.

Ryzhkova, E., \& Prosvirkin, N. (2015). "Cluster initiatives as a competitiveness factor of modern enterprises". European Research Studies, Vol. 18, No. 3, pp. 21-30.

Schumpeter A.J. (1942). Capitalism, Socialism, and Democracy. New York: Harper Brothers.

Simonin, B.L. (1999). "Ambiguity and the process of knowledge transfer in strategic alliances". Strategic management journal, Vol. 20, No. 7, pp. 595-623.

Skrodzka, I. (2016). "Knowledge-Based Economy in the European Union-Crosscountry Analysis". STATISTICS, Vol. 17, No. 2, pp. 281-294.

Stelzer I.M. (2002). "Innovation, price competition and the 'tilt' of competition policy", Economic Affairs, Vol. 22, No.4, pp. 25-31.

Stevens, J. (2002). Applied multivariate statistics for the social sciences, 4th ed., Lawrence Erlbaum, Mahwah, NJ.

Strat, V.A., Nancu, D., Begu, L.S., Dan, M.C., Hadad, S. (2018). "Directing renewable energy-oriented Small and Medium Enterprises (SMEs) towards rural areas", Sustainability, under revision.

Tabachnick, B.G. \& Fidell, L.S., (2007). Using multivariate statistics, 5th edn., Pearson, Boston, MA. 
United Nations Statistics Division. (2013). "Composition of macro geographical (continental) regions, geographical sub-regions, and selected economic and other groupings". Available online http://hero.epa.gov/index.cfm?action=search.view\&reference_id=597420.

Van Rompuy, H. (2012). "Remarks by President Herman Van Rompuy following the European Council", Available online http://europa.eu/rapid/pressrelease_PRES-12-533_en.htm.

Vatamanescu, E.M., Nistoreanu, B.G., \& Mitan, A. (2017). "Competition and consumer behavior in the context of the digital economy". Amfiteatru Economic, Vol. 19, No. 45, pp. 354-366.

Vizitiu, C., Agapie, A., Paiusan, R., Hadad, S., \& Nastase, M. (2018). "Adapting corporate entrepreneurship assessment instrument for Romania". South African Journal of Business Management, Vol. 49, No. 1, pp. 7, 1-7.

Voinescu, R., \& Moisoiu, C. (2015). "Competitiveness, theoretical and policy approaches. Towards a more competitive EU". Procedia Economics and Finance, Vol. 22, pp. 512-521.

World Bank (2009, 2012). "Measuring Knowledge in the World's economies, Knowledge for Development, Retrieved from www.worldbank.org/wbi/k4d.

World Economic Forum (2013). "The Global Competitiveness Report 2012-2013", SRO-Kundig, Switzerland.

World Economic Forum (2016). "The Global Competitiveness Report 2015-2016", SRO-Kundig, Switzerland Available online http://reports.weforum.org/globalcompetitiveness-report-2015-2016/methodology/.

Zhang H., Shu C., Jiang X., Malter A.J. (2010). "Managing Knowledge for Innovation: The Role of Cooperation, Competition, and Alliance Nationality", Journal of International Marketing, Vol. 18, No. 4, pp. 74-94.

**World Bank Database https://data.worldbank.org/. 


\section{Annex 1}

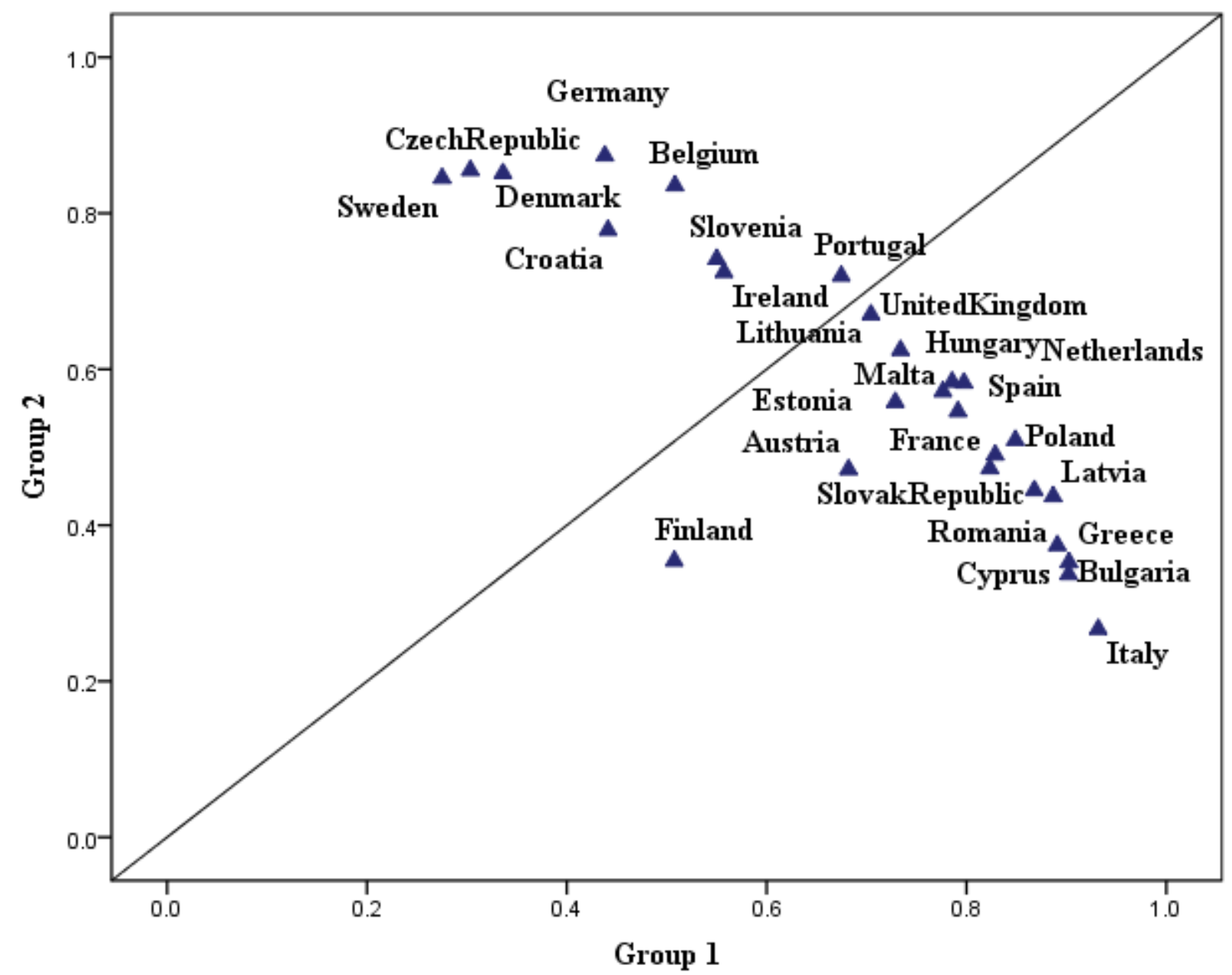

Figure 2. Distribution of EU countries with respect to Knowledge Economy - case without Gini

Source: Author's representation based on own research. 


\section{Annex 2}

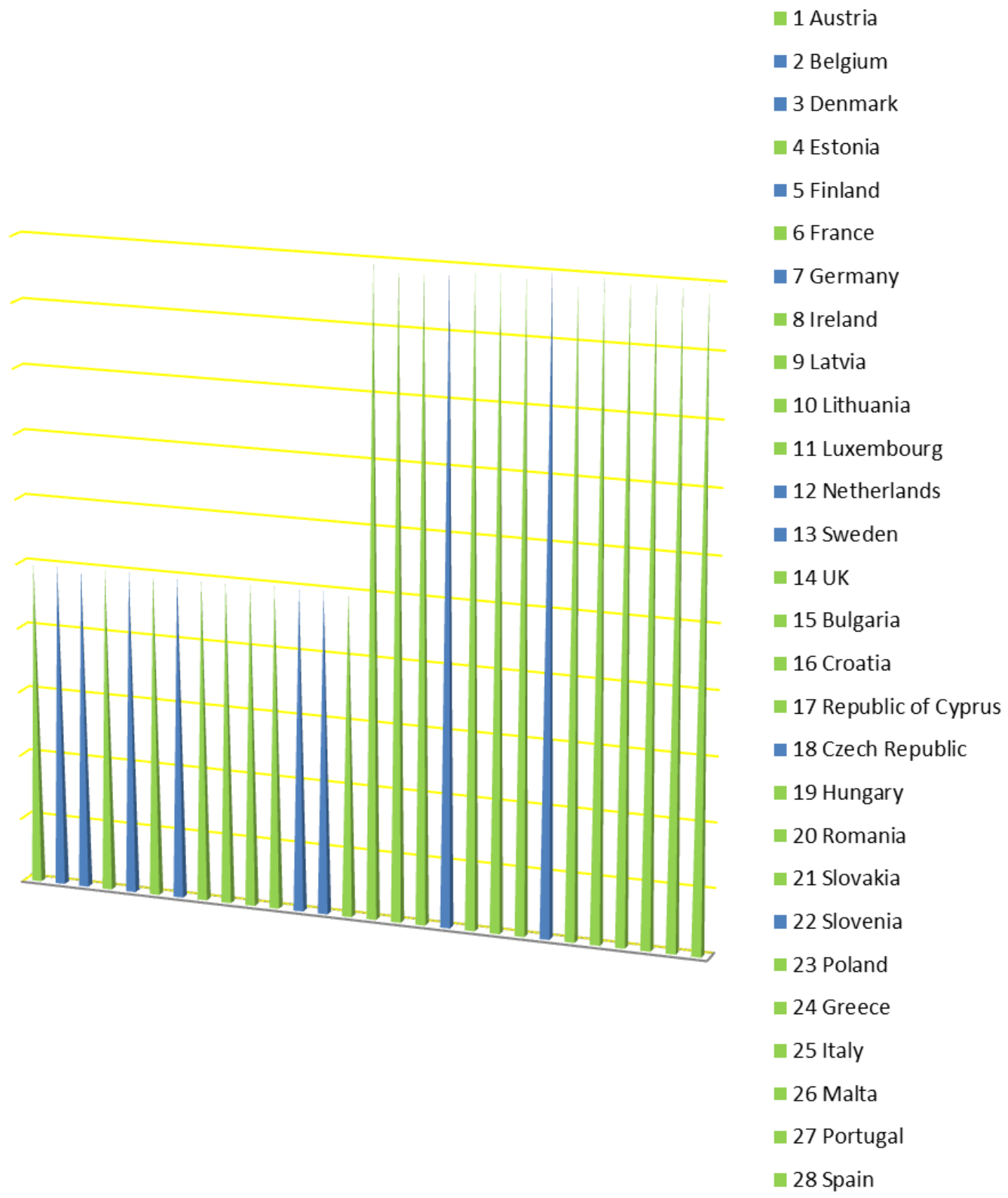

Figure 3. Geographical vs FA clusters

Source: Author's representation based on own research. 